\title{
DNA barcoding of the fungal genus Neonectria and the discovery of two new species
}

\author{
ZHAO Peng ${ }^{1,2}$, LUO Jing $^{1}$, ZHUANG WenYing ${ }^{*}{ }^{*}$ LIU XingZhong $^{1}$ \& WU Bing ${ }^{1,2}$ \\ ${ }^{1}$ State Key Laboratory of Mycology, Institute of Microbiology, Chinese Academy of Sciences, Beijing 100101, China; \\ ${ }^{2}$ Graduate University of Chinese Academy of Sciences, Beijing 100049, China
}

Received March 28, 2011; accepted May 4, 2011

\begin{abstract}
To determine a suitable DNA barcode for the genus Neonectria, the internal transcribed spacer rDNA, $\beta$-tubulin, EF- $1 \alpha$, and RPB2 genes were selected as candidate markers. A total of 205 sequences from 19 species of the genus were analyzed. Intraand inter-specific divergences and the ease of nucleotide sequence acquisition were treated as criteria to evaluate the feasibility of a DNA barcode. Our results indicated that any single gene among the candidate markers failed to serve as a successful barcode, while the combination of the partial EF-1 $\alpha$ and RPB2 genes recognized all species tested. We tentatively propose the combined partial EF-1 $\alpha$ and RPB2 genes as a DNA barcode for the genus. During this study, two cryptic species were discovered, based on the combined data of morphology and DNA barcode information. We described and named these two new species $N$. ditissimopsis and $N$. microconidia.
\end{abstract}

intra-specific variation, inter-specific variation, morphology, DNA barcode, sequence analysis

Citation: Zhao P, Luo J, Zhuang W Y, et al. DNA barcoding of the fungal genus Neonectria and the discovery of two new species . Sci China Life Sci, 2011, 54: 664-674, doi: 10.1007/s11427-011-4184-8

Rapid and precise identification of species is the vital and critical first step in the fields of conservation, sustainable use of biodiversity [1], ecology [2], pathogen prevention and control [3], quarantine control of exotic species [4], forensic investigations [5], and human health [6,7]. Using purely morphological methods to identify fungal species poses some problems. The number of taxonomic mycologists is very limited, and for a specific fungal group fewer specialists can be consulted. Furthermore, morphological identification is somewhat time-consuming especially of species that lack sufficient diagnostic features, such as unicellular groups or those that fail to sporulate. In the past two decades, analysis of DNA sequences has been incorporated to establish phylogenetic relationships among groups and to aid species delimitation [8-12]. Nowadays, efforts have been made to seek a short, standardized, and universal gene

*Corresponding author (email: zhuangwy@im.ac.cn) marker for rapid species identification of diverse groups of fungi [5,13-19]. So far, a single universal DNA barcode for fungi has not been obtained [20]. Attempts have been made to develop a molecular identification system based on multilocus species identification, rather than a single locus [21].

Neonectria, a genus of the family Nectriaceae, was redefined, and three species were first accepted with the genus Cylindrocarpon as anamorphs by Rossman et al. [22]. Species belonging to the Nectria mammoidea-Group, Nectria rugulosa-Group, Nectria radicicola-Group and Nectria veuillotiana-Group were later assigned to the genus [23,24]. More recently, quite a few species were added to the genus [25-32]. As the number of species increased, it became necessary to investigate a DNA barcode for the genus to get a better understanding of the species diversity of the group. In this study, we used ITS (rDNA internal transcribed spacer), $\beta$ tubulin, EF-1 $\alpha$ (elongation factor $1 \alpha$ ), and RPB2 (RNA 
polymerase second largest subunit) genes, which have been widely used in the exploration of phylogeny among species, to select a suitable DNA barcode for Neonectria. The intraand inter-specific divergences and ease of nucleotide sequence acquisition were treated as criteria to evaluate the feasibility of a DNA barcode.

During the screening of DNA barcodes for the genus Neonectria, two cryptic species were described as new species. One of them is closely related to Nectria ditissima and Nectria major, and the other is associated with Nectria confusa and its allies.

\section{Materials and methods}

\subsection{Materials studied}

A total of 82 strains representing 19 species of the genus Neonectria were sampled, including the type species $\mathrm{Nec}$ tria ramulariae (Table 1 ).

\subsection{Morphological study}

The methods of Rossman et al. [22] and Luo and

Table 1 Materials used in this study

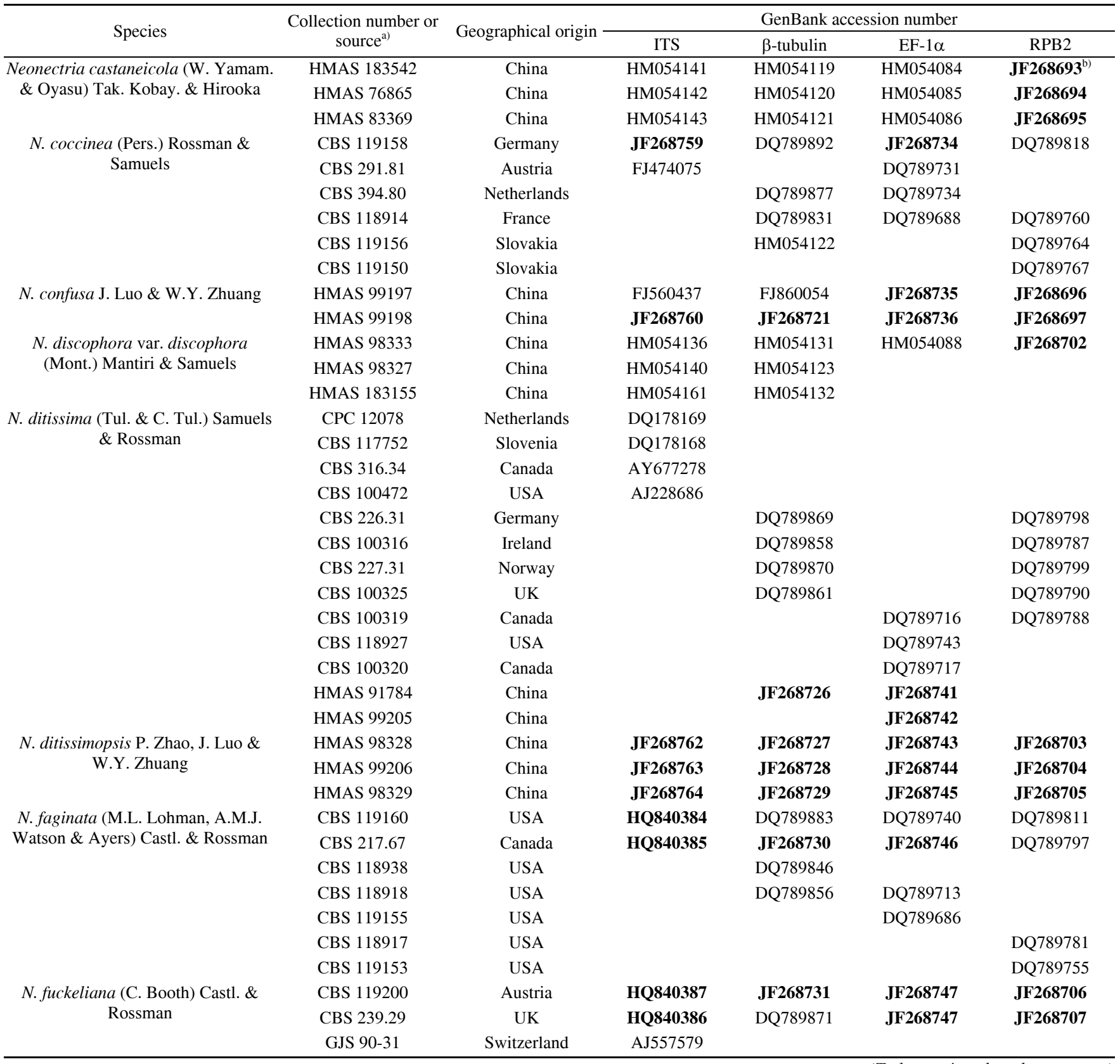


(Continued)

\begin{tabular}{|c|c|c|c|c|c|c|}
\hline \multirow{2}{*}{ Species } & \multirow{2}{*}{$\begin{array}{l}\text { Collection number or } \\
\text { source }^{\text {a) }}\end{array}$} & \multirow{2}{*}{ Geographical origin } & \multicolumn{4}{|c|}{ GenBank accession number } \\
\hline & & & ITS & $\beta$-tubulin & $\mathrm{EF}-1 \alpha$ & RPB2 \\
\hline $\begin{array}{c}\text { N. hubeiensis W.Y. Zhuang, Y. Nong } \\
\text { \& J. Luo }\end{array}$ & HMAS 98331 & China & FJ560439 & FJ860056 & HM054090 & JF268708 \\
\hline \multirow[t]{7}{*}{ N. liriodendri Halleen, Rego \& Crous } & CBS 112607 & South Africa & & AY677241 & & \\
\hline & CBS 112610 & France & AY677270 & AY677244 & JF268749 & JF268709 \\
\hline & STE-U6624 & South Africa & & GU183660 & & \\
\hline & STE-U6625 & South Africa & & GU183661 & & \\
\hline & CBS 117527 & Portugal & DQ178165 & & & \\
\hline & CBS 110.81 & USA & DQ178163 & & & \\
\hline & CBS 112602 & South Africa & AY997532 & & & \\
\hline \multirow{6}{*}{$\begin{array}{c}\text { N. macrodidyma Halleen, Schroers \& } \\
\text { Crous }\end{array}$} & CBS 112605 & South Africa & AY997549 & AY677230 & & \\
\hline & CBS 112594 & South Africa & & AY677231 & & \\
\hline & CBS 112603 & South Africa & & AY677232 & & \\
\hline & CBS 112615 & South Africa & AY677290 & AY677233 & JF268750 & JF268710 \\
\hline & CBS 112601 & South Africa & JF268765 & & JF268751 & JF268711 \\
\hline & KRP 51-1 & Lithuania & HM036602 & & & \\
\hline N. major (Wollenw.) Castl. \& & HMAS 183183 & China & JF268766 & JF268732 & JF268752 & JF268712 \\
\hline \multirow[t]{5}{*}{ Rossman } & HMAS 183184 & China & JF268767 & JF268733 & JF268753 & JF268713 \\
\hline & CBS 118981 & France & & DQ789833 & & \\
\hline & CBS 119229 & France & & DQ789834 & & DQ789763 \\
\hline & CBS 240.29 & Norway & & DQ789872 & DQ789729 & DQ789800 \\
\hline & CBS 118982 & USA & & & & DQ789782 \\
\hline \multirow{4}{*}{$\begin{array}{c}\text { N. microconidia J. Luo, P. Zhao \& } \\
\text { W.Y. Zhuang }\end{array}$} & HMAS 98295 & China & JF268761 & JF268722 & JF268737 & JF268698 \\
\hline & HMAS 98293 & China & & JF268723 & JF268738 & JF268699 \\
\hline & HMAS 98294 & China & & JF268724 & JF268739 & JF268700 \\
\hline & HMAS 98296 & China & & JF268725 & JF268740 & JF268701 \\
\hline \multirow{2}{*}{$\begin{array}{l}\text { N. neomacrospora (C. Booth \& } \\
\text { Samuels) Mantiri \& Samuels }\end{array}$} & CBS 118984 & Canada & HQ840388 & DQ789882 & JF268754 & DQ789810 \\
\hline & CBS 118985 & Canada & HQ840389 & DQ789890 & JF268755 & DQ789816 \\
\hline \multirow{3}{*}{$\begin{array}{c}\text { N. punicea (J.C. Schmidt) Castl. \& } \\
\text { Rossman }\end{array}$} & CBS 119724 & Austria & JF268768 & DQ789824 & JF268756 & DQ789753 \\
\hline & CBS 152.29 & Germany & AY677260 & & & \\
\hline & CBS 242.29 & Germany & & DQ789873 & DQ789730 & DQ789801 \\
\hline N. radicicola (Gerlach \& L. Nilsson) & CBS 153.37 & France & HQ840391 & AY677251 & JF268757 & JF268714 \\
\hline \multirow[t]{3}{*}{ Mantiri \& Samuels } & CBS 156.47 & Belgium & HQ840390 & AY677252 & JF268758 & JF268715 \\
\hline & NTU 103 & China & FJ205457 & & & \\
\hline & MH 337 & Czech Republic & FJ430728 & & & \\
\hline \multirow[t]{5}{*}{ N. ramulariae Wollenw. } & & & DQ350126 & & & \\
\hline & CBS 182.36 & & HM054157 & DQ789864 & HМ054092 & DQ789793 \\
\hline & CBS 151.29 & UK & AY677291 & DQ789863 & HМ054091 & DQ789792 \\
\hline & CBS 730.87 & Germany & AJ279446 & DQ789879 & & \\
\hline & ATCC 16237 & Germany & & DQ789857 & & DQ789786 \\
\hline $\begin{array}{c}\text { N. shennongjiana J. Luo \& W.Y. } \\
\text { Zhuang }\end{array}$ & HMAS 183185 & China & FJ560440 & FJ860057 & HМ054093 & JF268716 \\
\hline N. veuillotiana (Sacc. \& Roum.) & HMAS 98332 & China & HМ054151 & HМ054133 & HМ054094 & JF268717 \\
\hline \multirow[t]{2}{*}{ Mantiri \& Samuels } & HMAS 99207 & China & HM054146 & HM054134 & HM054095 & JF268718 \\
\hline & CBS 124740 & USA & HM054149 & HM054126 & HM054096 & JF268719 \\
\hline $\begin{array}{c}\text { Nectria pseudotrichia (Schwein.) } \\
\text { Berk. \& M.A. Curtis }\end{array}$ & HMAS 183172 & China & GU232860 & HМ054116 & HM054081 & JF268720 \\
\hline
\end{tabular}

a) ATCC: American Type Culture Collection, Bethesda, MD, USA; CBS: Centraalbureau voor Schimmelcultures, Utrecht, the Netherlands; CPC: Culture collection of P. W. Crous, housed at CBS; GJS: G. J. Samuels; HMAS: Mycological Herbarium, Institute of Microbiology, Chinese Academy of Sciences, Beijing, China; MH: M. Hujslová; NTU: National Taiwan University; STE: Departement van Plantkunde, Universiteit van Stellenbosch, Stellenbosch, South Africa; b) GenBank accession numbers in bold indicate the sequences generated in this study.

Zhuang [31,32] were generally followed for morphological characterization. Water was used as mounting fluid for microscopic examinations and measurements, and photographs were taken from water or lactic acid mounts with a Canon G5 (Tokyo, Japan) digital camera connected to a Zeiss Axioskop 2 plus microscope (Göttingen, Germany). The color names of colonies follow Ridgway's nomenclature [33]. Specimens are deposited in the Mycological Herbarium, Institute of Microbiology, Chinese Academy of Sciences, Beijing, China.

\subsection{DNA extraction, PCR amplification, and sequencing}

Genomic DNA was extracted from mycelia using the CTAB method [34]. Complete ITS rDNA was amplified and sequenced with ITS5 and ITS4 (or ITS1 and ITS4) primers [8]. A partial $\beta$-tubulin gene was PCR amplified with the primers T1 and T224 (or T22, T222) and sequenced with primers $\mathrm{T} 1$ and $\mathrm{Bt} 2 \mathrm{~b}[10,35]$. The partial EF- $1 \alpha$ gene was amplified by the primer pair 526F (or 728F) and 1567R. The amplicon was sequenced with the primers EFjR or 1567Ra in 
addition to the amplification primers $526 \mathrm{~F}$ or $728 \mathrm{~F}[36,37]$ (http://www.aftol.org/pdfs/EF1primer.pdf), and the region between $728 \mathrm{~F}$ and EFjR was analyzed. The taxon specific primers for EF-1 $\alpha$ gene, nEF-1 (5'-CACGTCGATTCTGGCAAGTC-3', forward), nEF-12 (5'-TTGGTGGTGTCCATCTTGTT-3', reverse), and nEF-13 (5'-GCGTTGTAGCCGACCTTCTT-3', reverse), were designed for PCR and sequencing when the commonly used primers did not perform well. The RPB2 gene was amplified with the primer pair fRPB2-5F and fRPB2-7cR [38]. The primers fRPB2-5F and RPB2intR [25] were used for sequencing. The following primers were designed for RPB2 amplification and sequencing, and used when necessary: nRPB2-147 (5'-TCGGCAARAAGCGWYTKGATC-3', forward); nRPB2-764 (5'-AYTTBCGKCGRGTATCCA-3', reverse); nRPB2-766 (5'-BGAYTTBCGKCGRGTATC-3', reverse).

PCR was performed with the 2720 Thermal Cycler (Applied Biosystems, Foster City, CA, USA) using a $25 \mu \mathrm{L}$ reaction system. For ITS, PCR conditions were an initial step of $5 \mathrm{~min}$ at $94^{\circ} \mathrm{C} ; 30$ cycles of $30 \mathrm{~s}$ at $94^{\circ} \mathrm{C}, 30 \mathrm{~s}$ at $53^{\circ} \mathrm{C}$, and $30 \mathrm{~s}$ at $72^{\circ} \mathrm{C}$; followed by $10 \mathrm{~min}$ at $72^{\circ} \mathrm{C}$. For $\beta$-tubulin, PCR conditions were an initial step of $5 \mathrm{~min}$ at $94^{\circ} \mathrm{C} ; 30$ cycles of $35 \mathrm{~s}$ at $94^{\circ} \mathrm{C}, 55 \mathrm{~s}$ at $53^{\circ} \mathrm{C}, 1 \mathrm{~min}$ or 2 min at $72^{\circ} \mathrm{C}$; followed by $10 \mathrm{~min}$ at $72^{\circ} \mathrm{C}$. For EF- $1 \alpha$, PCR conditions were an initial step of $5 \mathrm{~min}$ at $94^{\circ} \mathrm{C} ; 10$ cycles of $30 \mathrm{~s}$ at $94^{\circ} \mathrm{C}, 55 \mathrm{~s}$ at $63^{\circ} \mathrm{C}$ or $66^{\circ} \mathrm{C}$ (decreasing $1^{\circ} \mathrm{C}$ per cycle), $90 \mathrm{~s}$ at $72^{\circ} \mathrm{C}$; plus 36 cycles of $30 \mathrm{~s}$ at $94^{\circ} \mathrm{C}, 55 \mathrm{~s}$ at $53^{\circ} \mathrm{C}$ or $56^{\circ} \mathrm{C}, 90 \mathrm{~s}$ at $72^{\circ} \mathrm{C}$; followed by $7 \mathrm{~min}$ at $72^{\circ} \mathrm{C}$. For RPB2, PCR conditions were an initial step of $5 \mathrm{~min}$ at $95^{\circ} \mathrm{C} ; 35$ cycles of $30 \mathrm{~s}$ at $94^{\circ} \mathrm{C}, 30 \mathrm{~s}$ at $55^{\circ} \mathrm{C}, 1 \mathrm{~min}$ or 90 s at $72^{\circ} \mathrm{C}$; followed by $10 \mathrm{~min}$ at $72^{\circ} \mathrm{C}$. The obtained amplicons were sequenced in both directions with an $\mathrm{ABI}$ 3730 XL DNA Sequencer (SinoGenoMax Co. Ltd., Beijing, China).

\subsection{Comparison of intra- and inter-specific divergences}

Sequences were aligned using ClustalX 1.81 [39] and manually edited to adjust the aligned sequences by BioEdit 7.0 [40]. A partition homogeneity test (PHT) was performed with 1000 replicates in PAUP 4.0b10 [41] to evaluate statistical congruence between sequence data from EF- $1 \alpha$ and RPB2 gene regions. The aligned sequences of each gene and the combined EF-1 $\alpha$ and RPB2 genes were analyzed using DNAstar 7.1.0 (Lasergene, USA) to calculate the similarity matrices and then illustrate the intra- and inter-specific variations of the candidate barcode loci for each of the 19 species tested in this study, using a visualization analysis tool, TaxonGap 2.4.1 [42]. As suggested by Martens et al. [43], Nectria pseudotrichia was designated as the outgroup in the analysis.

The other distance-dependent method for evaluation the sequence variations within and between species of the potential barcode regions using Kimura's two-parameter (K2P) model, with clustering at a given threshold, was generated with TaxonDNA 1.6.3 [44].

\subsection{Evaluation of the ease of test barcode sequence acquisition}

Success rates of PCR amplification and sequencing of the considered DNA barcode markers for the genus were assessed. A single PCR band obtained was considered as successful amplification. A high quality chromatogram counted as successful sequencing. The success rate of PCR amplification multiplied by that of sequencing produced the overall success rate of PCR amplification and sequencing.

\subsection{Neighbor-joining tree reconstruction}

A neighbor-joining tree was constructed based on sequence analysis of the combined EF- $1 \alpha$ and RPB2 genes using MEGA 4.0.2 [45] with the K2P substitution model to show the relationships among the Neonectria species. Branch support was calculated by a bootstrap analysis with 1000 replicates, and N. pseudotrichia was used as the outgroup.

\section{Results}

\subsection{Selection of DNA barcode markers for Neonectria}

A total of 205 sequences of the four candidate DNA barcode regions, ITS, $\beta$-tubulin, EF- $1 \alpha$ and RPB2 genes, from 19 Neonectria species were analyzed (Table 1). To meet the requirements for a standard DNA barcode, the sequences of all the candidate markers must be short, i.e., $412-475$ base pairs (bp) for ITS, 489-515 bp for $\beta$-tubulin, 461-478 bp for EF- $1 \alpha$ and 473 bp for RPB2.

Intra- and inter-specific variation, clustering with a given threshold, and the success rate of PCR and sequencing were used to evaluate the feasibility of the candidate markers [46]. Among them, intra- and inter-specific variation was treated as a very important criterion. The successful species identification of a DNA barcode requires a clear distinction between intra- and inter-specific divergences [47]. The intraand inter-specific variations of the candidate DNA barcode regions for each of the 19 Neonectria species generated using TaxonGap [42] indicated that the EF-1 $\alpha$ gene provided a somewhat better resolution compared with the ITS, $\beta$-tubulin, and RPB2 genes (Figure 1). For the EF-1 $\alpha$ gene, the smallest inter-specific variation was $1.7 \%$, which is shown as a thin and black line in Figure 1. All species, except for $N$. confusa and $N$. veuillotiana, had intra-specific variations lower than $1.7 \%$. When the $\beta$-tubulin gene was tested, the minimum inter-specific variation between $N$. confusa and Nectria punicea was only $0.7 \%$, the intra-specific variations of four species (Nectria discophora var. 


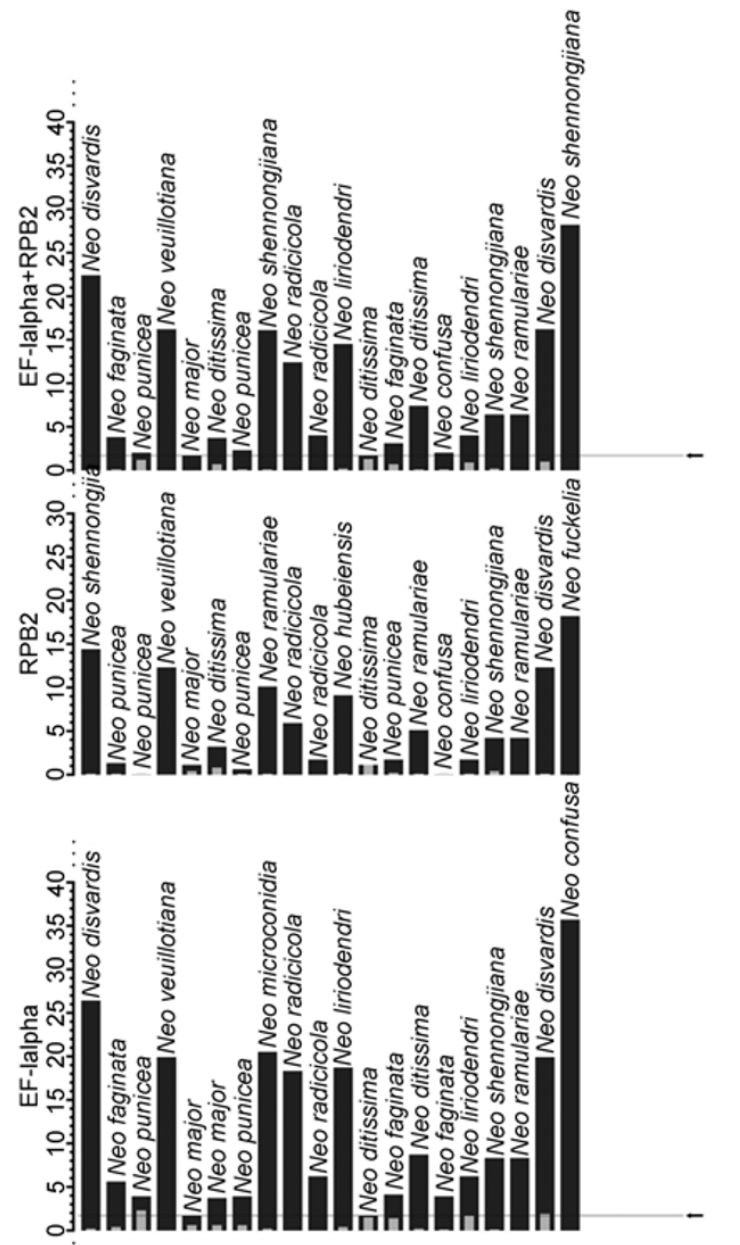

$\stackrel{9}{\rightleftarrows}$

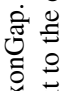

放

这

o

定

空

这:

응

ธัँ

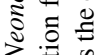

2.

总

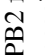

㖓.

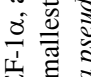


discophora, $N$. ditissima, $N$. major and $N$. ramulariae) exceeded the smallest inter-specific variation. The species identification abilities of ITS and RPB2 genes were even worse, and thus the thin and black line cannot be detected. Thus, no individual DNA marker could serve as a suitable barcode; therefore, gene combinations were considered. When the EF-1 $\alpha$ and RPB2 genes were combined, the analysis provided a fairly good result in that all intra-specific variations were lower than the smallest inter-specific variation (Figure 1).

Clustering with a given threshold was calculated using TaxonDNA [44], which provided additional measurements of the intra- and inter-specific divergences for the candidate barcode markers (Table 2). The largest intra-specific distance was employed as the threshold of clustering to explore the coincidence of a cluster and its correlation with a single species. For the EF-1 $\alpha$ gene, a total of 18 clusters were recognized, which means this gene separated 17 of the 19 species $(89.5 \%)$; RPB2 and $\beta$-tubulin genes discriminated
16 and 12 species, respectively; and ITS was able to identify only 10 species. When RPB2 gene and EF- $1 \alpha$ gene were combined, all examined species were identified successfully.

The success rate of PCR and sequencing was one of the criteria to estimate candidate barcode markers. EF- $1 \alpha$, RPB2, and $\beta$-tubulin genes were easily PCR amplified and sequenced, and the success rates reached $100 \%$. New primer pairs were required for RPB2 and EF- $1 \alpha$ genes from a few species, although the commonly used primers worked well in most species of the genus. Unexpectedly, ITS scored a relatively low success rate $(83.7 \%)$.

The partition homogeneity test $(P=0.018)$ suggested that the individual partitions were congruent $[48,49]$. EF- $1 \alpha$ and RBP2 sequences were therefore combined for the subsequent analysis. In the neighbor-joining tree generated from the combined EF-1 $\alpha$ and RPB2 genes, all species were well-separated from each other as independent terminal branches (Figure 2). Sequences from different strains of the

Table 2 Clustering at a given threshold of the candidate barcode genes ITS, $\beta$-tubulin, EF- $1 \alpha$ and RPB2 of nineteen Neonectria species derived using TaxonDNA [44]

\begin{tabular}{|c|c|c|c|c|c|}
\hline Candidate gene $(\mathrm{s})$ & ITS & $\beta$-tubulin & EF-1 $\alpha$ & RPB2 & $\mathrm{EF}-1 \alpha+\mathrm{RPB} 2$ \\
\hline Largest intra-specific distance & $1.07 \%$ & $2.41 \%$ & $2.57 \%$ & $1.07 \%$ & $1.30 \%$ \\
\hline Number of cluster & 12 & 14 & 18 & 17 & 19 \\
\hline Corresponding to species taxa & $10(52.6 \%)$ & $12(63.2 \%)$ & $17(89.5 \%)$ & $16(84.2 \%)$ & $19(100 \%)$ \\
\hline
\end{tabular}

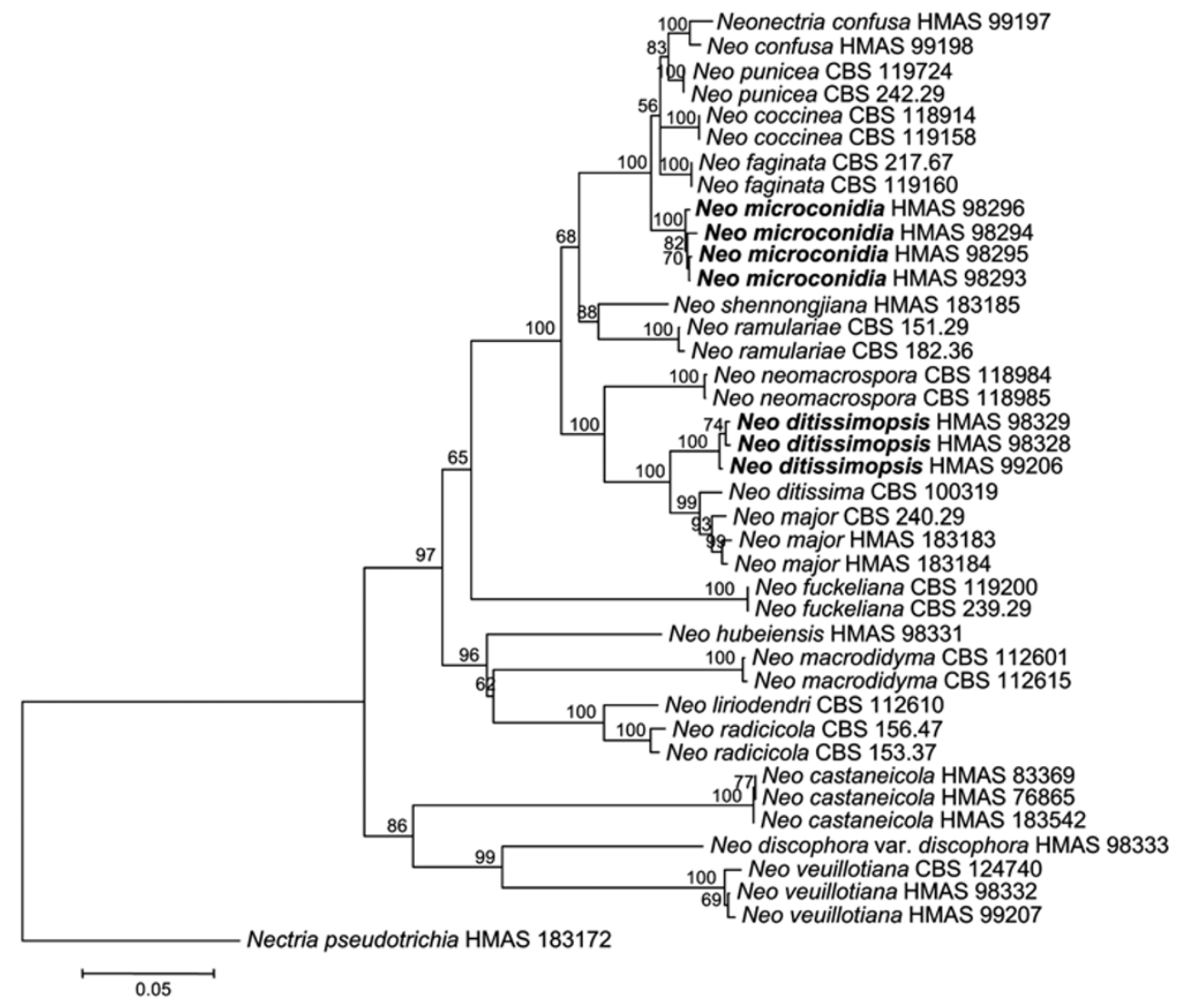

Figure 2 A neighbor-joining tree generated by analysis of the combined sequences of the EF-1 $\alpha$ and RPB2 genes (TreeBase: S11186). 
same species showed high cohesion. The three Neonectria strains (HMAS 98238, 98239, 99206) at the same terminal branch with $100 \%$ bootstrap support and closely related to and distinctive clearly from $N$. ditissima, and the four strains (HMAS 98293, 98294, 98295, 98296) at a same terminal branch with high bootstrap value $(100 \%)$ associated $N$. confusa and its allies, were found to be cryptic species of the genus.

\subsection{Taxonomy}

Neonectria ditissimopsis P. Zhao, J. Luo \& W.Y. Zhuang, sp. nov. (Figures 3A and 4)

\section{MycoBank MB519626}

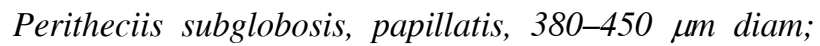

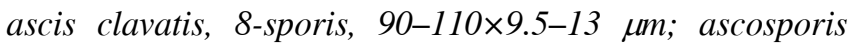
ellipsoideis, uniseptatis, spinulosis, 19-23.5×6.5-7.5 $\mu \mathrm{m}$.

Ascomata perithecial, gregarious up to 20 in a group, with a well-developed stroma that is erumpent through bark,

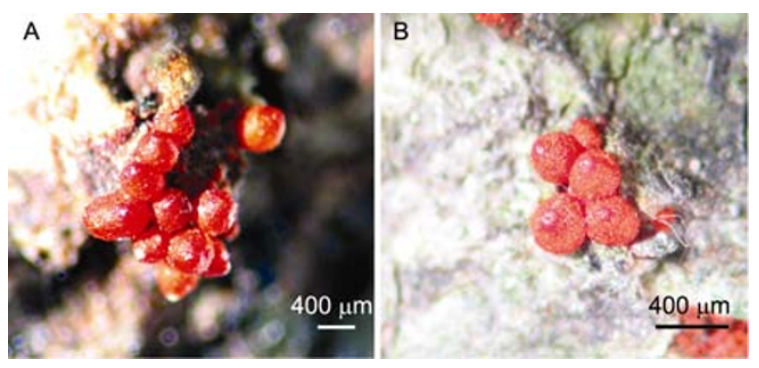

Figure 3 Ascomata on natural substrate. A, Neonectria ditissimopsis (HMAS 98329); B, Neonectria microconidia (HMAS 98294). superficial, subglobose, 420-510 $\mu \mathrm{m}$ high, 380-450 $\mu \mathrm{m}$ diam, with a small papilla, not collapsing when dry, red when fresh and brown red when dry, turning dark red in 3\% $\mathrm{KOH}$ and orange-red to orange in lactic acid, rough to slightly warted; warts red, 10-20 $\mu \mathrm{m}$ high, cells angular, 6.5-16×5-10 $\mu \mathrm{m}$, cell wall 1.5-2.5 $\mu \mathrm{m}$ thick. Ascomatal wall 38-60 $\mu \mathrm{m}$ thick, of two layers; outer layer $27-44 \mu \mathrm{m}$ thick, cells angular, 7.5-20.5×6-9 $\mu \mathrm{m}$, cell wall 1.5-2.5 $\mu \mathrm{m}$ thick; inner layer 11-16.5 $\mu \mathrm{m}$ thick, cells flattened, 16-27x $2-5 \mu \mathrm{m}$, cell wall $0.5-1.5 \mu \mathrm{m}$ thick. Asci subcylindrical to clavate, 8-spored, with an apical ring, 90-110×9.5-13 $\mu \mathrm{m}$ $(n=50)$. Ascospores fusoid-ellipsoid, uniseptate, not constricted at septum, hyaline, spinulose, irregularly biseriate, 19-23.5×6.5-7.5 $\mu \mathrm{m}(n=50)$. Anamorph unknown.

Colonies on PDA $2.8 \mathrm{~cm}$ in diam after $4 \mathrm{~d}$ in dark at $24^{\circ} \mathrm{C}$, Capucine Yellow, surface floccus, aerial mycelium yellowish, reverse pigmented, Raw Sienna. Colonies on CMD reaching $2.2 \mathrm{~cm}$ after $4 \mathrm{~d}$ in dark at $24^{\circ} \mathrm{C}$, Pale Yellow-Orange, aerial mycelium spare, reverse pigmented, Orange-Buff. Conidia not produced in culture.

Etymology: Specific epithet refers to the morphological similarity to $N$. ditissima.

Holotype: CHINA. HUBEI, Shennongjia, $1800 \mathrm{~m}$, on twigs of a dicotyledon tree, 16 Sept 2004, W.Y. Zhuang and Y. Nong 5748, HMAS 98329.

Paratypes: HUBEI: Shennongjia, $1800 \mathrm{~m}$, on twigs of a dicotyledon tree, 16 Sept 2004, W.Y. Zhuang and Y. Nong 5742, 5743, 5749, HMAS 98328, 99206, 98330.

Notes: Among the known species of the genus, N. ditissimopsis is most similar to $N$. ditissima in the subglobose
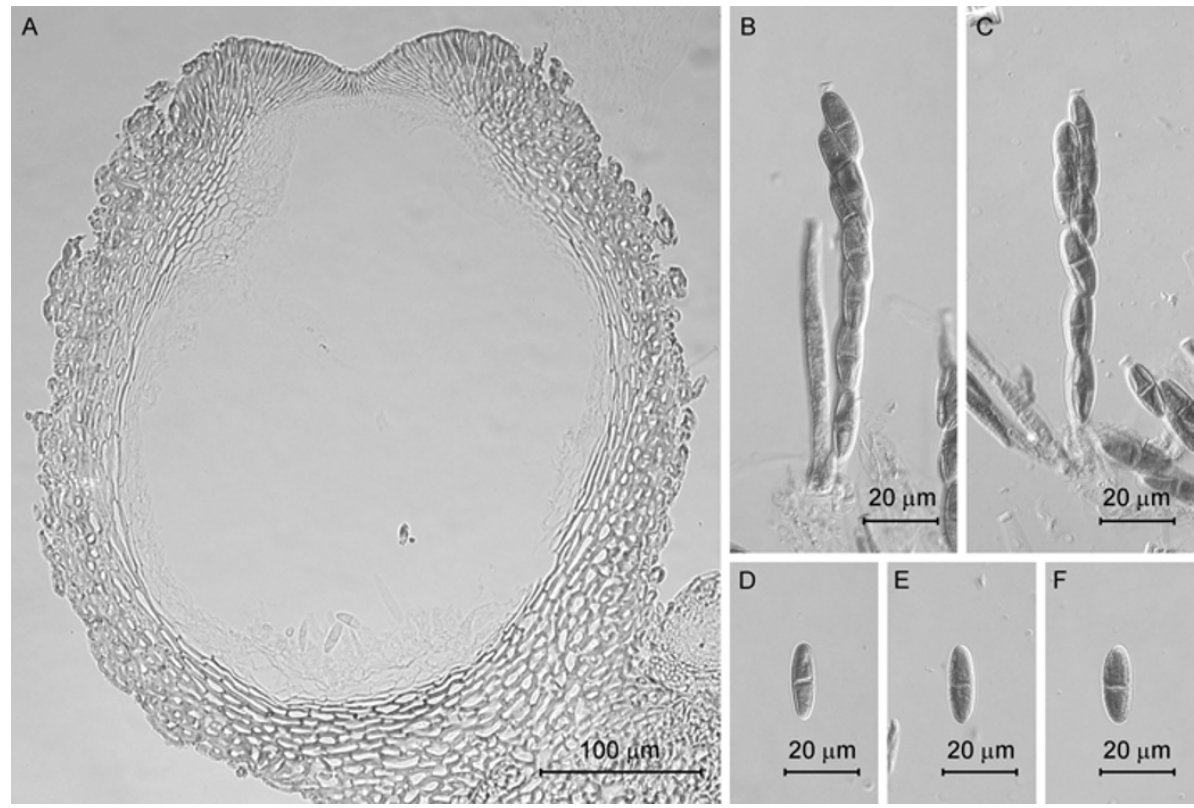

Figure 4 Morphology of Neonectria ditissimopsis (HMAS 98329). A, median section of an ascoma; B and C, asci; D-F, ascospores. 
perithecia, which do not collapse when dry and have a rough surface, subcylindrical to clavate asci, and spinulose ascospores. However, $N$. ditissima differs from $N$. ditissimopsis in somewhat smaller perithecia $(250-400 \mu \mathrm{m}$ diam), wider asci [(77-)88-116(-130)×(11-)12-17(-20) $\mu \mathrm{m}]$, the lack of an apical ring, and shorter ascospores [(12.2-)14.9$18.9(-24.3) \times(5.5-) 6.5-8.3(-10.2) \mu \mathrm{m}]$ [25]. The new species is also similar to $N$. coccinea in the subglobose perithecia, which do not collapse when dry and have a rough surface, the thickness of the perithecial wall, cylindrical to clavate asci with an apical ring, and spinulose ascospores. However, N. coccinea differs in smaller perithecia (200$350 \mu \mathrm{m}$ diam), smaller asci [(71-)76-93(-98) $\times(7-) 8-10$ $(-11) \mu \mathrm{m}]$, and much smaller ascospores [(10.5-)12.4$14.4 \times 5.1-6.5(-8.5) \mu \mathrm{m}][25,50,51]$.

In addition to the morphological characteristics, recognition of this new species and its close relation to $N$. ditissima were also supported by sequence analysis of the combined EF-1 $\alpha$ and RPB2 genes (Figure 2), which will be discussed later.

Neonectria microconidia J. Luo, P. Zhao \& W.Y. Zhuang, sp. nov. (Figures 3B and 5)

MycoBank MB561075

Peritheciis subglobosis, papillatis, 210-340 um diam; ascis cylindricis, 8-sporis, 65-90×5-9 $\mu \mathrm{m}$; ascosporis ellipsoideis, uniseptatis, 11-15×4-6 $\mu \mathrm{m}$.

Ascomata perithecial, gregarious, up to 50 in a group, on a well-developed stroma, superficial, subglobose to obpyriform, 245-360 $\mu \mathrm{m}$ high, 210-340 $\mu \mathrm{m}$ diam, with a small papilla, not collapsing when dry, orange-red when fresh and red when dry, turning dark red in $3 \% \mathrm{KOH}$ and orange red to orange in lactic acid, surface smooth. Ascomatal wall 25-42 $\mu \mathrm{m}$ thick, of two layers; outer layer 20-28 $\mu \mathrm{m}$ thick, cells angular, 7-17×5-10 $\mu \mathrm{m}$, cell wall $0.5-2.5 \mu \mathrm{m}$ thick; inner layer 4.5-15 $\mu \mathrm{m}$ thick, cells flattened, 9-29×2-5.5 $\mu \mathrm{m}$, cell wall $0.5-1.5 \mu \mathrm{m}$ thick. Asci cylindrical to broadly cylindrical, 8-spored, with an apical ring, 65-90×5-9 $\mu \mathrm{m}$ $(n=50)$. Ascospores fusoid to ellipsoid, uniseptate, not constricted at septum, hyaline to yellowish, warted, irregularly biseriate, $11-15 \times 4-6 \mu \mathrm{m}(n=50)$.

Colonies on PDA $3.2 \mathrm{~cm}$ in diam after $4 \mathrm{~d}$ in dark at $24^{\circ} \mathrm{C}$, Argus Brown, surface floccus, aerial mycelium yellowish, reverse pigmented, Antique Brown. Colonies on CMD reaching $2.5 \mathrm{~cm}$ after $4 \mathrm{~d}$ in dark at $24^{\circ} \mathrm{C}$, Buckthorn Brown, aerial mycelium spare, reverse pigmented, Ochraceous Tawny. Conidiophores simple. Simple conidiophores unbranched to sparsely branched, septate, 20-55×1.5-2.5 $\mu \mathrm{m}$, conidiogenous cells monophialidic, cylindrical, 15$27.5 \mu \mathrm{m}$ long, 1-2.5 $\mu \mathrm{m}$ at base, $0.5-1 \mu \mathrm{m}$ near aperture. Microconidia ellipsoid to cylindrical, not or slightly curved, hyaline, $0-1$-septate; 0-septate: $3-12 \times 1.5-2.5 \mu \mathrm{m} \quad(n=50)$, 1-septate: $6.5-13 \times 1.5-3.5 \mu \mathrm{m} \quad(n=50)$. Macroconidia or Chlamydospores not observed.

Etymology: Specific epithet refers to producing purely microconidia in culture.

Holotype: CHINA. HUBEI, Wufeng, $800 \mathrm{~m}$ alt., on twigs, 13 Sept 2004, W.Y. Zhuang and Y. Nong 5639, HMAS 98294.

Paratypes: CHINA. HENAN, Jigongshan, $400 \mathrm{~m}$ alt., on twigs, 14 Nov 2003, W.Y. Zhuang and Y. Nong 5129, HMAS 91750. HUBEI, Wufeng, Houhe Nature Reserve, $800 \mathrm{~m}$ alt., on twigs, 12 Sept 2004, W.P. Wu, W.Y. Zhuang

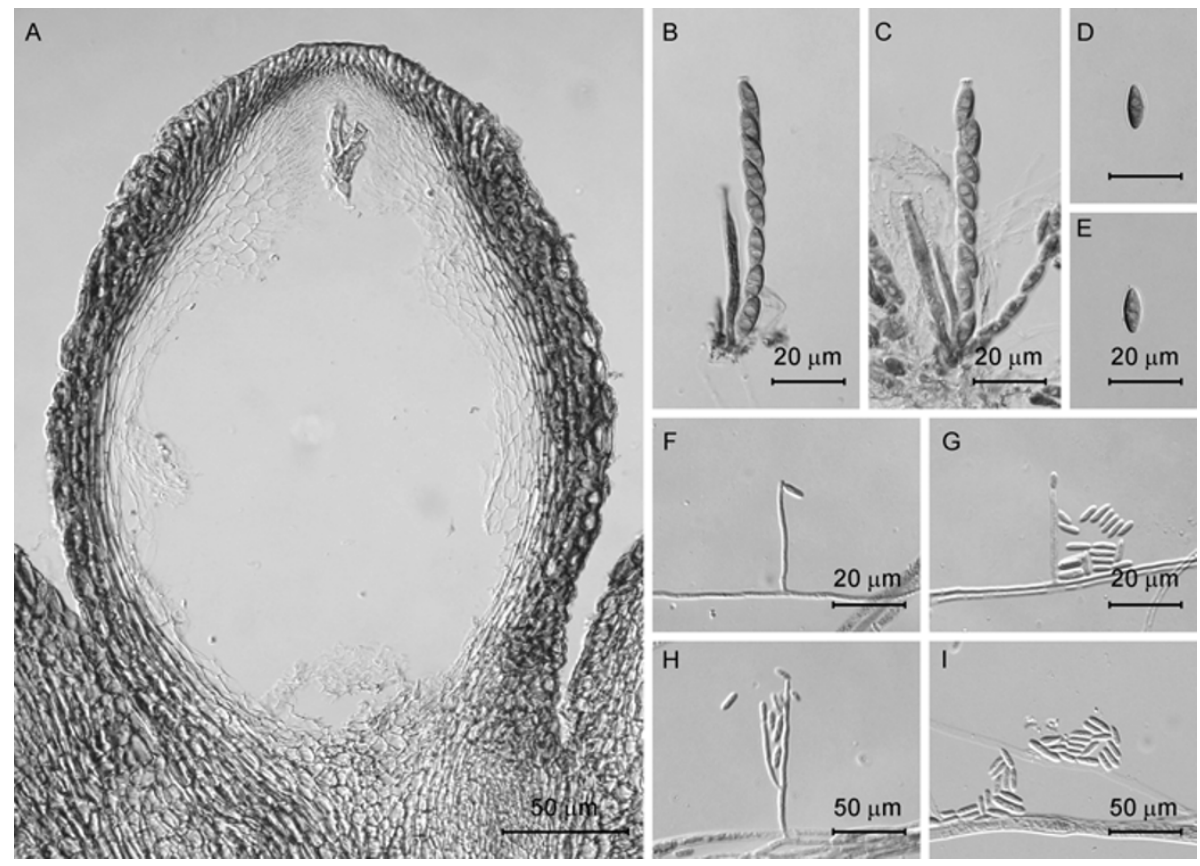

Figure 5 Morphology of Neonectria microconidia (HMAS 98294). A, median section of an ascoma; B and C, asci; D and E, ascospores; F-H, conidiophores bearing microconidia; I, microconidia. 
and Y. Nong 5544, 5550, HMAS 99196, 98292; ibid., on twigs, 12 Sept 2004, W.Y. Zhuang and Y. Nong 5554, HMAS 98293; ibid., on twigs, 13 Sept 2004, W.Y. Zhuang and Y. Nong 5642, HMAS 98295; ibid., on bark, 13 Sept 2004, W.Y. Zhuang and Y. Nong 5640, HMAS 98296.

Notes: Among the existing species of the genus, N. microconidia is most similar to $N$. confusa in smooth and subglobose perithecia, which do not collapse when dry, cylindrical asci with an apical ring, fusoid ascospores with a warted surface, ellipsoid to cylindrical microconidia, and brown colony on PDA. N. confusa, however, differs in smaller ascomata $(205-260 \times 175-240 \mu \mathrm{m})$, thinner ascomatal wall (18-30 $\mu \mathrm{m}$ thick), slightly smaller ascospores $(9-13 \times 3.5-5 \mu \mathrm{m})$, and producing abundant macroconidia in culture [32]. The DNA sequence divergences support strongly the separation of $N$. microconidia from $N$. confusa (Figure 2). Different strains of any one of the two species share very similar sequences. We treat the above distinctions at the species level.

\section{Discussion}

As previously indicated, the two important criteria for estimating a DNA barcode are suitable intra- and inter-specific sequence variation and high success rate of PCR amplification and sequencing. In our study, the success rates of PCR amplification and sequencing for all tested markers were more or less the same because of the new primer pairs introduced. Therefore, a suitable intra- and inter-specific sequence variation becomes critical. Our results suggest that the combination of partial EF- $1 \alpha$ and RPB2 genes may serve as the DNA barcode for the genus Neonectria.

As a qualified DNA barcode, a short, single DNA fragment should be distinct enough to separate a wide range of species. The fact that fungi display extremely high species diversity among living organisms may cause problems during determination of a universal barcode. In the case of Neonectria, when a single DNA fragment is considered as a barcode marker, the EF- $1 \alpha$ and RPB2 genes were both better than the ITS and $\beta$-tubulin genes. The EF-1 $\alpha$ gene possessed more or less adequate intra- and inter-specific variations, and therefore had the highest species identification power among the candidate markers. It is able to recognize 17 of the 19 species tested $(89.5 \%$, Table 2$)$, with the exception of the two closely related species. RPB2 gene ranks the next $(16 / 19,84.2 \%$, Table 2$)$. This result conforms to the previous studies in certain other fungal groups [38,52-54]. The other two genes, $\beta$-tubulin and ITS, had undesirable intra- and inter-variations and exhibited relatively poor species resolution capacity (Table 2 ), which indicated that the partial $\beta$-tubulin gene and ITS gene are inadequate to identify closely related species. The low inter-specific variation in ITS failed to discriminate closely related species (Figure
1), which was also reported in other groups of fungi [55-57] and thus limits its application as a DNA barcode [20].

A two-locus DNA barcode, the combination of plasmid genes $r b c L$ and $m a t K$, was adopted recently as the main barcode of land plants [58]. In our case, no single gene could serve as a powerful DNA barcode. We thus proposed to use two gene fragments instead one as the barcode for the group. The combination of the EF- $1 \alpha$ and RPB2 genes recognized all species of the genus (Figure 1; 19/19, 100\%, Table 2). This is because the three species (N. confusa, Nectria faginata and $N$. punicea) that the RPB2 gene failed to identify can easily be separated by the EF-1 $\alpha$ gene. Similarly, the two species ( $N$. ditissima and $N$. major) that the EF-1 $\alpha$ gene was unable to distinguish are well-differentiated by the RPB2 gene. These two gene fragments appear to be complementary and work jointly as the DNA barcode of Neonectria.

During our screening of the DNA barcode, attention was also paid to the establishment of the correct species concepts for this group of fungi. The neighbor-joining tree generated by combined sequences of the EF-1 $\alpha$ and RPB2 genes indicates that collections formerly treated as $N$. ditissima (as Nectria galligena) and N. confusa were not completely identical in DNA sequences, although their morphological distinctions were relatively few or negligible at the species level. The sequence analysis and inter- and intra-specific variations displayed by these collections led to the discovery of two cryptic species, $N$. ditissimopsis and $N$. microconidia (Figures 1-5). The former was previously merged with $N$. ditissima [30], and the latter was treated as an intra-specific variant of $N$. confusa, based on morphological and culture characteristics [32].Our sequence analysis also revealed that $N$. ditissimopsis is closely related to $N$. ditissima, N. major, and Nectria neomacrospora, with $100 \%$ bootstrap value, which is in accordance with their morphological similarity. Neonectria microconidia is closely related to $N$. confusa, $N$. coccinea, $N$. punicea, and $N$. faginata, also with $100 \%$ bootstrap support. Detailed morphological comparisons between $N$. microconidia and $N$. confusa have already been discussed.

DNA barcoding is becoming a helpful tool in the assessment of biodiversity. Discovery of cryptic species by DNA barcoding has been reported in butterfly [59] and yew [60]. The current work suggests that integrated studies on morphology and DNA sequence data have a bright future in the exploration of fungal diversity and the establishment of clear species concepts.

This work was supported by the National Natural Science Foundation of China (Grant Nos. 31070015 and 31000009), the Knowledge Innovation Program of the Chinese Academy of Sciences (Grant No. KSCX2-EW-J-6), and Research on Network of Applied Microbes of the Chinese Academy of Sciences (Grant No. KSCX2-YW-G-068). 
1 Ardura A, Linde A R, Moreira J C, et al. DNA barcoding for conservation and management of Amazonian commercial fish. Biol Conserv, 2010, 143: 1438-1443

2 Chen X Y, Daniell T J, Neilson R, et al. A comparison of molecular methods for monitoring soil nematodes and their use as biological indicators. Eur J Soil Biol, 2010, 46: 319-324

3 Crous P W, Groenewald J Z, Risède J M, et al. Calonectria species and their Cylindrocladium anamorphs: species with clavate vesicles. Stud Mycol, 2006, 55: 213-226

4 Wingfield M J, Slippers B, Roux J, et al. Worldwide movement of exotic forest fungi, especially in the tropics and the southern hemisphere. Bioscience, 2001, 51: 134-140

5 Boehme P, Amendt J, Disney R H L, et al. Molecular identification of carrion-breeding scuttle flies (Diptera: Phoridae) using COI barcodes. Int J Legal Med, 2010, 124: 577-581

6 Schwarz P, Bretagne S, Gantier J C, et al. Molecular identification of zygomycetes from culture and experimentally infected tissues. J Clin Microbiol, 2006, 44: 340-349

7 Lowenstein J H, Burger J, Jeitner C W, et al. DNA barcodes reveal species-specific mercury levels in tuna sushi that pose a health risk to consumers. Biol Lett, 2010, 6: 692-695

8 White T J, Bruns T, Lee S, et al. Amplification and direct sequencing of fungal ribosomal RNA genes for phylogenetics. In: Innis M A, Gelfand D H, Sninsky J J, et al., eds. PCR Protocols: A Guide to Methods and Applications. New York: Academic Press, 1990. 315-322

9 Bruns T D, White T J, Taylor J W. Fungal molecular systematics. Ann Rev Ecol Syst, 1991, 22: 525-564

10 O'Donnell K, Cigelnik E. Two divergent intragenomic rDNA ITS2 types within a monophyletic lineage of the fungus Fusarium are nonorthologous. Mol Phylogenet Evol, 1997, 7: 103-116

11 James T Y, Kauff F, Schoch C L, et al. Reconstructing the early evolution of Fungi using a six-gene phylogeny. Nature, 2006, 443: 818-822

12 Hibbett D S, Binder M, Bischoff J F, et al. A higher-level phylogenetic classification of the Fungi. Mycol Res, 2007, 111: 509-547

13 Geiser D M, Klich M A, Frisvad J C, et al. The current status of species recognition and identification in Aspergillus. Stud Mycol, 2007, 59: $1-10$

14 Min X J, Hickey D A. Assessing the effect of varying sequence length on DNA barcoding of fungi. Mol Ecol Notes, 2007, 7: 365-373

15 Seifert K A, Samson R A, de Waard J R, et al. Prospects for fungus identification using CO1 DNA barcodes, with Penicillium as a test case. Proc Natl Acad Sci USA, 2007, 104: 3901-3906

16 Tedersoo L, Jairus T, Horton B M, et al. Strong host preference of ectomycorrhizal fungi in a Tasmanian wet sclerophyll forest as revealed by DNA barcoding and taxon-specific primers. New Phytol, 2008, 180: 479-490

17 Feau N, Vialle A, Allaire M, et al. Fungal pathogen (mis-) identifications: A case study with DNA barcodes on Melampsora rusts of aspen and white poplar. Mycol Res, 2009, 113: 713-724

18 Eberhardt U. A constructive step towards selecting a DNA barcode for fungi. New Phytol, 2010, 187: 265-268

19 Stockinger H, Krüger M, Schüßler A. DNA barcoding of arbuscular mycorrhizal fungi. New Phytol, 2010, 187: 461-474

20 Seifert K A. Progress towards DNA barcoding of fungi. Mol Ecol Res, 2009, 9: 83-89

21 Roe A D, Rice A V, Bromilow S E, et al. Multilocus species identification and fungal DNA barcoding: insights from blue stain fungal symbionts of the mountain pine beetle. Mol Ecol Res, 2010, 10: 946-959

22 Rossman A Y, Samuels G J, Rogerson C T, et al. Genera of Bionectriaceae, Hypocreaceae and Nectriaceae (Hypocreales, Ascomycetes). Stud Mycol, 1999, 42: 1-248

23 Mantiri F R, Samuels G J, Rahe J E, et al. Phylogenetic relationships in Neonectria species having Cylindrocarpon anamorphs inferred from mitochondrial ribosomal DNA sequences. Can J Bot, 2001, 79: 334-340

24 Brayford D, Honda B M, Mantiri F R, et al. Neonectria and Cylindrocarpon: the Nectria mammoidea group and species lacking mi- croconidia. Mycologia, 2004, 96: 572-597

25 Castlebury L A, Rossman A Y, Hyten A S. Phylogenetic relationships of Neonectria/Cylindrocarpon on Fagus in North America. Can J Bot, 2006, 84: 1417-1433

26 Halleen F, Schroers H, Groenewald J Z, et al. Neonectria liriodendri sp. nov., the main causal agent of black foot disease of grapevines. Stud Mycol, 2006, 55: 227-234

27 Hirooka Y, Kobayashi T, Natsuaki K T, et al. Neonectria amamiensis and Cylindrocarpon amamiense, a new nectrioid fungus and its sporodochial anamorph on Pinus luchuensis from Japan. Mycoscience, 2006, 47: 248-256

28 Samuels G J, Rossman A Y, Chaverri P, et al. Hypocreales of the Southeastern United States: An Identification Guide. CBS Biodiversity Series 4. Utrecht, the Netherlands: Cebtraalbureau voor Schimmelcultures, 2006. 1-145

29 Hirooka Y, Kobayashi T. Taxonomic studies of nectrioid fungi in Japan I: the genus Neonectria. Mycoscience, 2007, 48: 53-62

30 Zhuang W Y, Nong Y, Luo J. New species and new Chinese records of Bionectriaceae and Nectriaceae (Hypocreales, Ascomycetes) from Hubei, China. Fungal Divers, 2007, 24: 347-357

31 Luo J, Zhuang W Y. Four new species and a new Chinese record of the nectrioid fungi. Sci China Life Sci, 2010, 53: 909-915

32 Luo J, Zhuang W Y. Three new species of Neonectria (Nectriaceae, Hypocreales) with notes on their phylogenetic positions. Mycologia, 2010, 102: 142-152

33 Ridgway R. Color Standards and Color Nomenclature. Ridgway, Washington, DC., USA, 1912

34 Wang L, Zhuang W Y. Designing primer sets for amplification of partial calmodulin genes from penicillia. Mycosystema, 2004, 23: 466-473

35 Glass N L, Donaldson G C. Development of primer sets designed for use with the PCR to amplify conserved genes from filamentous ascomycetes. Appl Environ Microb, 1995, 61: 1323-1330

36 Carbone I, Kohn L M. A method for designing primer sets for speciation studies in filamentous ascomycetes. Mycologia, 1999, 91: 553-556

37 Rehner S A, Buckley E. A Beauveria phylogeny inferred from nuclear ITS and EF1- $\alpha$ sequences: evidence for cryptic diversification and links to Cordyceps teleomorphs. Mycologia, 2005, 97: 84-98

38 Chaverri P, Castlebury L A, Overton B E, et al. Hypocrea/Trichoderma: species with conidiophore elongations and green conidia. Mycologia, 2003, 95: 1100-1140

39 Thompson J D, Higgins D G, Gibson T J. CLUSTAL W: improving the sensitivity of progressive multiple sequence alignments through sequence weighting, position specific gap penalties and weight matrix choice. Nucleic Acids Res, 1994, 22: 4673-4680

40 Hall TA. BioEdit: a user-friendly biological sequence alignment editor and analysis program for Windows 95/98/NT. Nucleic Acids Symp Ser, 1999, 41: 95-98

41 Swofford DL. PAUP*: phylogenetic analysis using parsimony (*and other methods). Version 4b10. Sunderland, Massachusetts: Sinauer Associates, 2002

42 Slabbinck B, Dawyndt P, Martens M, et al. TaxonGap: a visualisation tool for intra- and inter-species variation among individual biomarkers. Bioinformatics, 2008, 24: 866-867

43 Martens M, Dawyndt P, Coopman R, et al. Advantages of multilocus sequence analysis for taxonomic studies: a case study using 10 housekeeping genes in the genus Ensifer (including former Sinorhizobium). Int J Syst Evol Microbiol, 2008, 58: 200-214

44 Meier R, Shiyang K, Vaidya G, et al. DNA barcoding and taxonomy in Diptera: A tale of high intraspecific variability and low identification success. Syst Biol, 2006, 55: 715-728

45 Tamura K, Dudley J, Nei M, et al. MEGA4: Molecular evolutionary genetics analysis (MEGA) software version 4.0. Mol Biol Evol, 2007, 24: $1596-1599$

46 Zhao P, Luo J, Zhuang W Y. Practice towards DNA barcoding of the nectriaceous fungi. Fungal Divers, 2011, 46: 183-191

47 Hebert P D, Cywinska A, Ball S L, et al. Biological identifications through DNA barcodes. Proc R Soc Lond, 2003, 270: 313-321 
48 Farris J S, Kallersjo M, Kluge A G, et al. Testing significance of incongruence. Cladistics, 1995, 10: 315-319

49 Cunningham $\mathrm{C}$ W. Can three incongruence tests predict when data should be combined? Mol Biol Evol, 1997, 14: 733-740

50 Booth C. Studies of Pyrenomycetes. IV. Nectria (Part 1). Mycol Pap, 1959, 73: 1-117

51 Booth C. The genus Cylindrocarpon. Mycol Pap, 1966, 104: 1-56

52 Zhong Z, Pfister D H. Phylogenetic relationships among species of Leotia (Leotiales) based on ITS and RPB2 sequences. Mycol Res, 2004, 3: 237-246

53 Frøslev T G, Matheny P B, Hibbett D S. Lower level relationships in the mushroom genus Cortinarius (Basidiomycota, Agaricales): A comparison of RPB1, RPB2, and ITS phylogenies. Mol Phylogenet Evol, 2005, 37: 602-618

54 Hansen K, LoBuglio K F, Pfister D H. Evolutionary relationships of the cup-fungus genus Peziza and Pezizaceae inferred from multiple nuclear genes: RPB2, $\beta$-tubulin and LSU rDNA. Mol Phylogenet Evol, 2005, 36: 1-23
55 Lieckfeldt E, Seifert K A. An evaluation of the use of ITS sequences in the taxonomy of the Hypocreales. Stud Mycol, 2000, 45: 35-44

56 Varga J, Frisvad J C, Samson R A. Polyphasic taxonomy of Aspergillus section Candidi based on molecular, morphological and physiological data. Stud Mycol, 2007, 59: 75-88

57 Crouch J A, Clarke B B, Hillman B I. What is the value of ITS sequence data in Colletotrichum systematics and species diagnosis? A case study using the falcate-spored graminicolous Colletotrichum group. Mycologia, 2009, 101: 648-656

58 Hollingsworth P M, Forrest L L, Spouge J L, et al. A DNA barcode for land plants. Proc Natl Acad Sci USA, 2009, 106: 12794-12797

59 Hebert P D, Penton E H, Burns J M, et al. Ten species in one: DNA barcoding reveals cryptic species in the neotropical skipper butterfly Astraptes fulgerator. Proc Natl Acad Sci USA, 2004, 101: 14812-14817

60 Liu J, MÖller M, Gao L M, et al. DNA barcoding for the discrimination of Eurasian yews (Taxus L. Taxaceae) and the discovery of cryptic species. Mol Ecol Res, 2011, 11: 89-100

Open Access This article is distributed under the terms of the Creative Commons Attribution License which permits any use, distribution, and reproduction in any medium, provided the original author(s) and source are credited. 